\title{
Pemberdayaan Usaha Kerajinan Anyaman Bambu Karya Kelompok Usaha Ibu-Ibu "Sari Murni" Desa Landih, Dusun Buayang-Bangli
}

\author{
I Gst. B Ngr. P. Putra ${ }^{1 *}$, Anak Agung Ketut Jayawarsa ${ }^{2}$, Ida Ayu Dinda Priyanka \\ Maharani $^{3}$, Putu Ary Setiyawan ${ }^{4}$ iD \\ ${ }^{1,2,3}$ Fakultas Ekonomi dan Bisnis Universitas Warmadewa, Indonesia \\ ${ }^{4}$ Fakultas Teknologi Informasi, Universitas Udayana, Indonesia \\ *Corresponding author: ngurahpanji.putra@gmaill.com
}

\begin{abstract}
Abstrak
Bambu merupakan salah satu tanaman yang memiliki tekstur lentur dan mudah dibentuk, sehingga cocok digunakan untuk membuat berbagai macam kerajinan berbasis anyaman. Namun dalam proses produksi anyaman bambu terdapat banyak kendala yang dirasakan oleh pengrajin seperti kurangnya ketersediaan sarana dan prasarana, kurangnya jangkauan pemasaran, serta kurangnya kemampuan pengarajin untuk membuat rancangan keuangan dengan baik. Tujuan dilaksanakan program kemitraan masyrakat ini adalah untuk mempertahankan keberlangsungan dari usaha kerajinan anyaman sokasi agar tetap terjaga dan tidak punah. Mitra yang terlibat dalam kegiatan ini yakni kelompok usaha "Sari Murni" yang merupakan kelompok usaha pengarajin anyaman bambu. Terdapat 3 program kerja yang dilankan dalam kegiatan ini, yakni pada bidang produksi dilaksanakan kegiatan penyediaan sarana dan prasarana penunjang produksi, pada bidang akuntansi yakni Pelatihan Pencatatan Transaksi Keuangan serta Penyediaan Sistem Pencatatan Keuangan Ter-digitalisasi, dan dengan bidang Manajemen Pemasaran serta Teknologi Informasi, yakni Penyediaan Website sebagai Bentuk Strategi Pemasaran dan Pelatihan Strategi Promosi. Hasil dari kegiatan ini yakni adanya peningkatan jangkauan penjualan produk, meningkatnya kualitas hasil produksi, serta peningkatan kemampun pengrajin dalam mengelola keuangan.
\end{abstract}

Kata Kunci: Kelompok Pengrajin Sari Murni, Kerajinan Tenun Sokasi

\section{Abstract}

Bamboo is a plant that has a flexible texture and is easy to shape, making it suitable for making various kinds of woven-based crafts. However, in the process of producing woven bamboo, there are many obstacles experienced by craftsmen such as the lack of availability of facilities and infrastructure, lack of marketing reach, and the lack of ability of the craftsmen to make good financial designs. The purpose of this community partnership program is to maintain the sustainability of the sokasi woven craft business so that it is maintained and does not become extinct. The partners involved in this activity are the "Sari Murni" business group, which is a business group for woven bamboo craftsmen. There are 3 work programs carried out in this activity, namely in the production sector, activities for providing production support facilities and infrastructure are carried out, in the accounting field, namely Training for Recording Financial Transactions and Providing a Digitalized Financial Recording System, and with the fields of Marketing Management and Information Technology, namely Website Provision as a Form of Marketing Strategy and Promotional Strategy Training. The results of this activity are an increase in the range of product sales, an increase in the quality of production, and an increase in the ability of craftsmen to manage finances

Keywords: Sari Murni Craftsmen Group, Sokasi Woven Crafts

\section{INTRODUCTION}

Bambu merupakan salah satu tanaman yan dapat hidup dengan baik di daerah tropis. Tanaman bambu memiliki sifat regeneratif dan nilai keindahan yang alami (Susanti et al., 2020). Bambu dikenal sebagai material yang ramah lingkungan dan sumber daya alam yang

$\begin{array}{ll}\text { History: } & \\ \text { Received } & \text { : April 05, } 2021 \\ \text { Revised } & \text { : April 09, } 2021 \\ \text { Accepted } & \text { : May 16, } 2021 \\ \text { Published } & \text { : May 25, } 2021\end{array}$


dapat diperbarui. Bambu memiliki tekstur yang sangat lentur dan mudah untuk dikreasikan menjadi berbagai macam prduk kerajinan (Malihah \& Achiria, 2019). Hal ini menjadikan bambu memiliki nilai tambah dan nilai guna tinggi ketika dapat diubah menjadi suatu produk (Lesmana et al., 2018). Terdapat sekitar 60 jenis produk yang dapat dibuat oleh tanaman bambu (Abdillah et al., 2017).

Salah satu daerah yang memanfaatkan bamboo sebagai produk kerajinan yakni Desa Landih-Dusun Buayang, Bangli. Desa Landih-Dusun Buayang menyimpan potensi kearifan lokal yakni kekayaan alam berupa tanaman bambu. Sudah banyak diketahui bahwa Kabupaten Bangli memang menjadi wilayah yang kaya akan tanaman bamboo, yang kemudian menjadikan desa tersebut sebagai salah satu sentra kerajinan anyaman bamboo yang dijual hingga mancanegara (Pratiwi, 2018; Roy et al., 2019). Pengrajin usaha kerajinan anyaman sokasi di Desa Landih-Dusun Buayang berasal dari kalangan ibu-ibu khususnya yang tergolong ke dalam kondisi perekonomian menengh kebawah, yang kemudian dibentuk menjadi komunitas pengrajin tanaman bambu.

Usaha kerajinan anyaman sokasi yang digeluti oleh kelompok menengah kebawah di Desa Landih tergolong ke dalam Usaha Mikro Kecil dan Menengah berskala industri rumah tangga. Produk kerajinan anyaman sokasi yang diproduksi oleh Kelompok Sari Murni sebagian besar menggunakan jenis bambu tali (Gigantochloa apus). Hal ini dikarenakan tekstur bambu tali yang luwes dan tidak terlalu keras sehingga lebih mudah untuk dianyam (Murti \& Murwandani, 2018). Keunggulan dari produk sokasi yang dihasilkan kelompok ini yakni hasil akhir yang lebih rapi dan halus karena dikerjakan oleh kalangan ibu-ibu rumah tangga sehingga proses pengerjaannya lebih telaten. Disamping itu, penggunaan bambu dua ruas menjadikan produk sokasi yang dihasilkan memiliki kualitas yang baik. Untuk meningkatkan nilai estetika dan nilai jual produk, kelompok pengrajin ini mencoba untuk berkreasi dan berinovasi dengan menghasilkan model sokasi berbagai varian ukuran dan juga motif corak yang beraneka- ragam seperti motif swastika, rangrang, sroni, motif nama, dan motif matahari.

Namun berdasarkan hasil diskusi bersama dengan mitra, yakni kelompok Kelompok Pemberdayaan Pengrajin Sokasi "Sari Murni" didapatkan informasi bahwa usaha kerajinan sokasi Kelompok Sari Murni kerap mengalami pasang surut bisnis. Permasalahan utama yang dihadapi yakni keterbatasan modal sehingga menyebabkan mitra kerap mengalami kesulitan dalam hal pemenuhan kebutuhan bahan baku bambu dan bahan penolong seperti pewarna cat, kuas, gergaji, dan pisau. Permasalahan kedua yang dihadapi yakni keterbatasan kemampuan dalam hal pencatatan transakasi keuangan. Kelompok usaha ini kerap mengalami kesulitan dalam menentukan aliran kas masuk dan keluar secara tepat. Proses pencatatan transaksi pun masih dilakukan secara manual. Permasalahan ini menjadi hal yang krusial untuk diperhatikan apabila dikaitkan dengan aspek permodalan. Permasalahan lain yang menghambat perkembangan usaha kerajinan anyaman sokasi Kelompok Sari Murni adalah terkait distribusi serta pemasaran produk yang masih dilakukan secara konvensional. Kemajuan teknologi digital di era globalisasi tanpa diimbangi dengan adanya kemampuan dalam pemanfaatan kemajuan IPTEK menyebabkan perkembangan usaha menjadi terhambat.

Salah satu upaya yang dapat dilakukan untuk mengatasi permaslaahn tersebut yakni dengan membentuk Program Kemitraan Masyarakat. Bentuk pemberdayaan mitra yang akan dilaksanakan yakni seperti program pendampingan mitra, pelatihan keahlian serta bantuan usaha dalam hal sarana dan prasarana. Terdapat 3 solusi yang ditawarkan untuk mengatasi permasalahan yang dialami oleh kelompok Sari Murni. Yang pertama adalah penyediaan sarana dan prasarana penunjang produksi. Sarana dan prasarana merupakan salah satu komponen penting yang dapat menunjang proses produksi. Sarana dan prasarana yang tidak lengkap serta sudah tidak berfungsi dengan baik tentu akan mempengaruhi kualitas produk kerajinan, sehingga ketersediaan sarana dan prasarana sangatlah dibutuhkan. 
Solusi kedua yang ditawarkan yakni pelatihan pencatatan transaksi keuangan serta penyediaan sistem pencatatan keuangan ter-digitalisasi. Latar belakang tim pengabdian menyediakan program pelatihan pembukuan terdigitalisasi adalah untuk meningkatkan efektivitas dan efisiensi dalam proses pencatatan transaksi keuangan. Perkembangan teknologi telah bergerak menjauh dari kebiasaan sebelumnya, misalnya model pembukuan keuangan dan penata layanan yang mulai ter-digitalisasi (Tata, 2019). Adapun sistem yang akan disediakan dan diperkenalkan kepada mitra pengabdian adalah sistem aplikasi dari pihak ketiga bernama aplikasi "Buku Kas". Aplikasi ini menyediakan berbagai macam fitur dan kemudahan dalam proses pencatatan transaksi keuangan. Fitur yang tersedia diantaranya input transaksi penjualan, pencatatan harga pokok penjualan, input transaksi pengeluaran, hingga pencatatan transaksi hutang dari supplier dan piutang dari customer (Ulfah \& Purfini, 2020). Sistem aplikasi ini juga dilengkapi dengan pengingat atas transaksi hutang maupun piutang yang telah jatuh tempo. Sistem akan memberikan reminder kepada pemilik usaha berkaitan dengan informasi nama supplier atau customer serta besaran nominal hutang atau piutang yang telah jatuh tempo (Warsadi et al., 2017). Hal yang terpenting adalah sistem aplikasi ini dapat menyediakan output berupa laporan keuangan hingga laporan hutang dan piutang disesuaikan dengan jangka waktu cut off yang dikehendaki. Ini akan memberikan kemudahan bagi mitra dalam mengawasi kegiatan usahanya. Luaran yang ditargetkan dari program ini yakni peningkatan keterampilan mitra dalam menentukan aliran kas masuk dan keluar dengan tepat, sehingga terjadi kesesuaian nominal saldo kas dalam pembukuan dengan saldo kas di tangan.

Program kerja ketiga yakni pelatihan digital marketing berupa penyediaan website sebagai bentuk media perantara antara pedagang dan calon customer. Strategi pemasaran berupa digital marketing sedang marak diterapkan oleh pelaku UMKM karena proses komunikasi dapat dilakukan secaa real time dan jangkauan transaksi lebih luas bahkan hingga mengglobal atau mendunia (Pradiani, 2018). Masyarakat yang bergerak di bidang usaha mikro, kecil, dan menengah (UMKM) memiliki jangkauan pasar yang lebih luas dengan penggunaan internet atau pemasaran berbasis online lainnya sehingga promosi atas suatu produk akan lebih optimal serta periklanan yang dilakukan pada media internet juga diimbangi dengan tingginya pemasaran melalui website (Haryono, 2018; Wastutiningsih \& Dewi, 2019).

Pemanfaaan media sosial menjadi faktor krusial yang mempengaruhi keberlangsungan UMKM, hal ini dikarenakan penggunan teknologi (media sosial) dapat membantu UMKM dalam meningkatkan penjualan sebesar 10-50\% (Berlilana et al., 2020). Media sosial merupakan fenomena baru yang telah mengubah cara lingkungan bisnis berjalan (Hidayat et al., 2017). Melalui media sosial kegiatan bisnis mendapatkan akses yang tidak terbatas hal ini bisa membantu perusahaan atau individu dapat meningkatkan kontak mereka dengan pelanggan dan pemasok. Menurut data Facebook pada 2014 6,6\% dari jumlah UKM di Indonesia memanfaatkan dunia digital terutama beriklan dengan menggunakan laman Facebook (Zahrul Atiq \& Syaichu, 2017). Melalui facebook apps penjual dapat melakukan optimalisasi kesadaran merk dengan membantu pengiklan untuk menemukan konsumen (Aprinta, 2016). Sementara Instagram apps dapat membantu pengiklanan untuk memasarkan produk melalui laman Instagram khususnya untuk menjangkau audiens yang lebih luas dengan lebih berfokus pada foto atau gambar (A. P. Putra \& Dewi, 2020). Ayu (2013) pada penelitiannya menyatakan bahwa "instagram merupakan aplikasi media sosial yang kehadirannya semakin dimaksimalkan sebagai media komunikasi pemasaran". Instagram memberikan manfaaat diantaranya adalah sebagai media promosi yang dianggap efektif oleh para informan, kedua sebagai media komunikasi antara pelaku bisnis dengan para konsumennya. Dan yang terakhir, instagram memberikan dampak terhadap peningkatan penjualan pada bisnis mereka" (Dewi, 2018). Lebih lanjut, Indika \& 
Jovita (2017) menyatakan bahwa Instagram merupakan salah satu media yang potensial untuk digunakan sebagai media promosi.

Berdasarkan pemaparan diatas dapat diketahui bahwa program penyediaan sarana dan prasarana penunjang produksi, pelatihan pencatatan transaksi keuangan serta penyediaan sistem pencatatan keuangan ter-digitalisasi, serta pelatihan digital marketing berupa penyediaan website efektif digunakan untuk mengatasi permasalahan kelompok pengrajin sari murni. Adapun tujuan pelaksanaan program ini adalah untuk keberlangsungan dari usaha kerajinan anyaman sokasi khas Desa Landih tetap terjaga dan tidak punah.
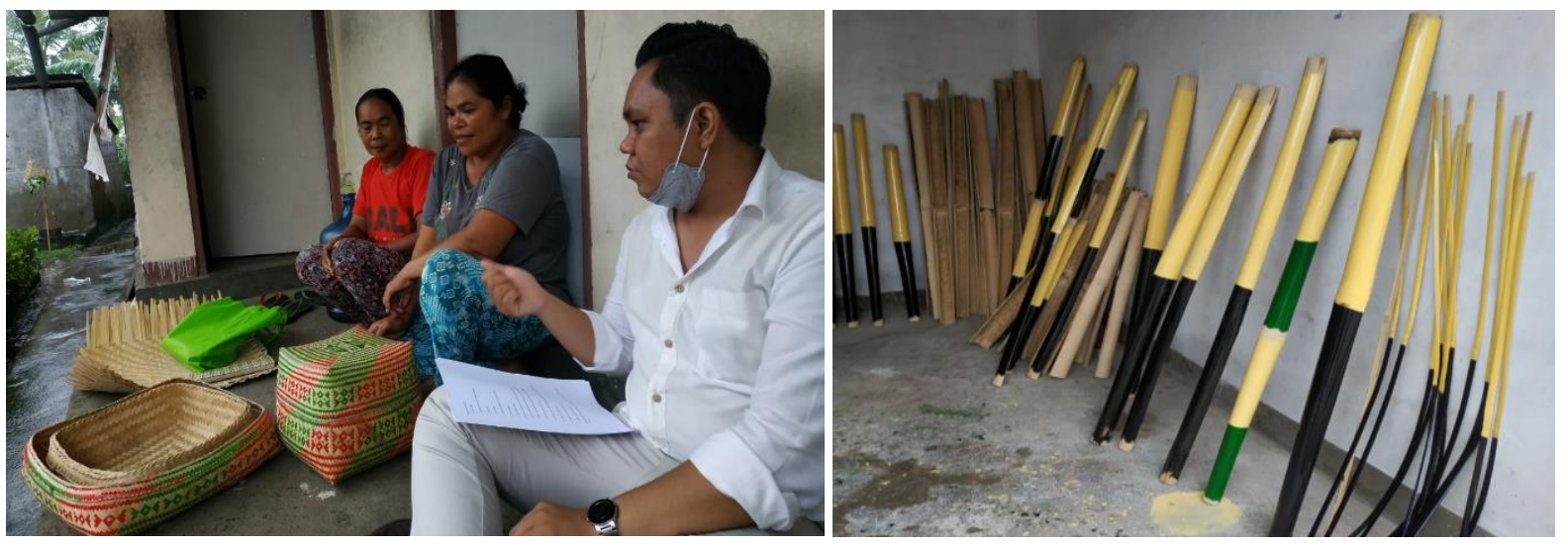

Gambar 1. Bahan Baku dan Produk Setengah Jadi Kerajinan Anyaman Sokasi
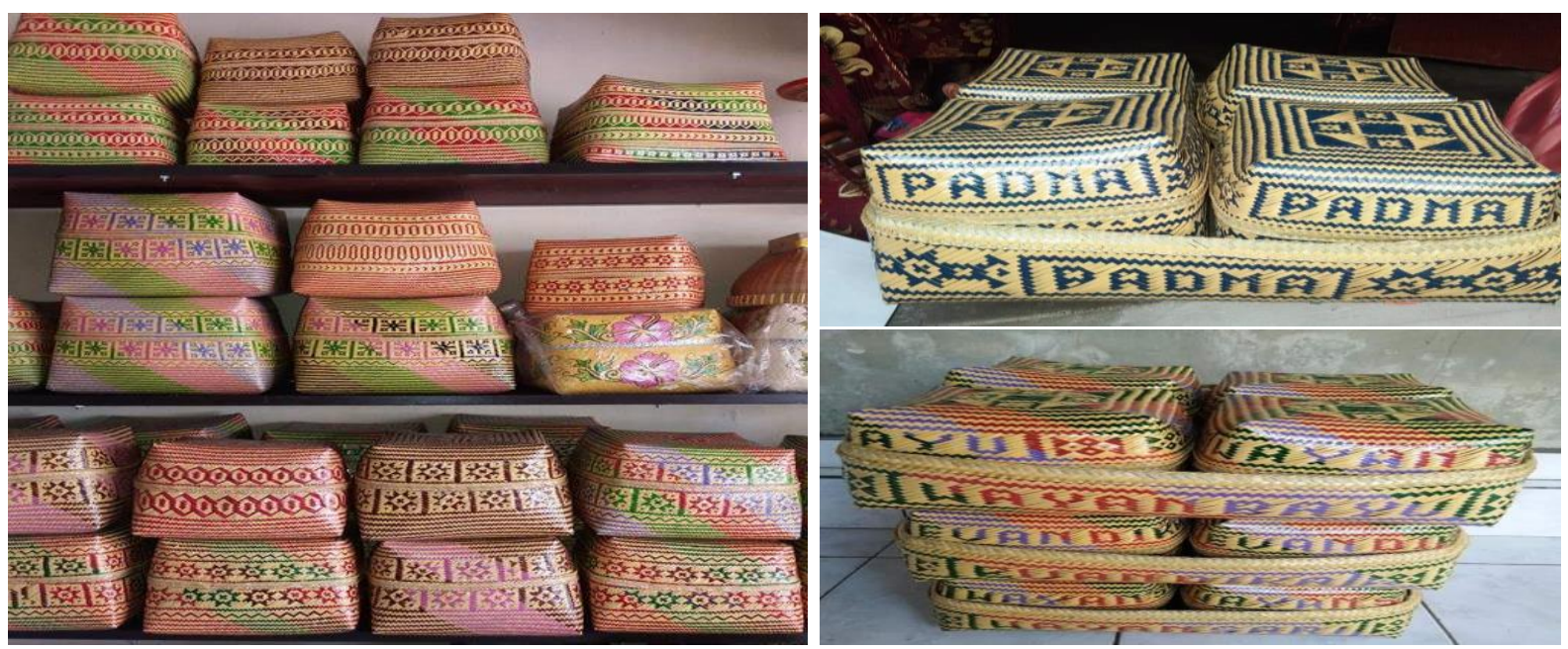

Gambar 2. Produk Kerajinan Anyaman Sokasi

\section{MATERIALS AND METHODS}

Program kemitraan masyarakat dilaksanakan dilaksanakan di Desa Landih-Dusun Buayang Bangli dengan melibatkan kelompok usaha pengrajin bambu "Sari Murni" yang berjumlah 14 orang sebagai mitra kegiatan. Kegiatan dilaksanakan dalam 2 kali pertemuan yakni pada tanggal 1 Mei dan 14 Mei 2021. Terdapat 3 program kerja utama yang dijalankan dalam kegiatan ini. Pertama pada bidang produksi dilaksanakan kegiatan penyediaan sarana dan prasarana penunjang produksi. latar belakang dilaksanakan program ini yakni, karena jenis usaha dari mitra pengabdian tergolong ke dalam usaha manufaktur dikarenakan terdapat kegiatan pengolahan bahan baku menjadi barang jadi. Untuk jenis usaha manufaktur, keberadaan bahan baku, bahan penolong, serta sarana prasarana produksi sangatlah krusial. 
Namun sangat disayangkan karena keterbatasan modal menyebabkan mitra kerap mengalami kesulitan dalam hal pemenuhan kebutuhan bahan baku bambu dan bahan penolong seperti pewarna cat. Beberapa dari peralatan produksi kerajinan anyaman sokasi pun telah kehabisan umur ekonomisnya, sehingga mempengaruhi proses dan kuantitas produksi produk.

Tahapan atau langkah-langkah pemecahan masalah tersebut yaitu pertama diadakan observasi dan survey terkait bahan baku, bahan penolong serta peralatan yang digunakan dalam proses produksi kerajinan anyaman sokasi, dan pencatatan terkait daftar yang perlu untuk diperbaharui. Tahap berikutnya adalah proses penyusunan anggaran dalam rangka pengadaan bahan baku, bahan penolong serta peralatan baru bagi mitra pengabdian disesuaikan dengan spesifikasi yang dibutuhkan. Selanjutnya seluruh tim pengabdi melakukan pengadaan bahan baku, bahan penolong serta peralatan produksi bagi mitra pengabdian. Tahap terakhir yaitu serah terima peralatan kepada mitra pengabdian.

Program kerja kedua berkaitan dengan bidang akuntansi yakni Pelatihan Pencatatan Transaksi Keuangan serta Penyediaan Sistem Pencatatan Keuangan Ter-digitalisasi. Tahapan pelaksanaan program kerja ini yaitu pertama penentuan saldo awal operasi, kemudian pencatatan aliran kas masuk yang terkait dengan aktivitas usaha seperti pendapatan usaha. Tahap berikutnya adalah pencatatan dan pengklasifikasian aliran kas keluar misalnya pembelian bahan baku atau bahan pembantu/penolong. Tahap terakhir adalah penentuan jumlah saldo kas di tangan dengan kas pada pencatatan pembukuan. Tim pengabdi juga memberikan penyediaan dan pelatihan sistem pencatatan keuangan ter-digitalisasi untuk mengatasi permasalahan mitra terkait proses pembukuan yang masih manual. Program kerja yang kami tawarkan ini merupakan bentuk adaptasi kegiatan usaha bisnis terhadap revolusi industri 4.0. Perkembangan teknologi yang terus bergerak di era Industri 4.0 mengakibatkan semua sektor harus mengikuti penggunaan teknologi yang sedang berkembang terutama di bidang teknologi informasi, penjualan onlinele-commerce, media sosial dan smartphone, dan marketplace berupa aplikasi berbasis android (Susanto et al., 2020). Dalam revolusi industri 4.0 yang terjadi adalah adanya otomatisasi dan digitalisasi segala aspek industri dan dalam rangka menghasilkan produk yang memuaskan kebutuhan konsumen (Oktaria Ardika Putri, 2019). Metode penyampaian materi yakni via laptop serta smartphone. Tahap pelaksanaanya adalah pengenalan sistem aplikasi pembukuan yang dikembangkan oleh pihak ketiga bernama aplikasi "Buku Kas". Tim pengabdian akan memperkenalkan fitur-fitur dari aplikasi tersebut. Selanjutnya dimulai tahap demonstrasi teknis penggunaan aplikasi Buku Kas disertai dengan contoh transaksi dummy agar lebih mudah dipahami mitra pengabdian.

Program kerja ketiga berkaitan dengan bidang Manajemen Pemasaran serta Teknologi Informasi, yakni Penyediaan Website sebagai Bentuk Strategi Pemasaran dan Pelatihan Strategi Promosi Secara Online via Facebook Apps dan Instagram Apps. Tahap awal kegiatan dilaksanakan dengan pembuatan website dengan menyediakan katalog produk disertai dengan varian jenis produk, harga, dan ukuran serta dilengkapi dengan link yang langsung terhubung ke aplikasi whatsapp sehingga akan memudahkan konsumen ketika melakukan pesanan pembelian. Dewasa ini media sosial tidak hanya terdapat pada layanan web layaknya facebook, twitter, instagram namun sudah banyak dijumpai pada smartphone yang berbasis chat seperti WhatsApp, Line dan Wechat, untuk kebutuhan promosi (Huda et al., 2019). Untuk mengoptimalkan dampak dari media sosial dan aplikasi chatting, tim pengabdian mengkombinasikan antara media website dengan aplikasi chatting berupa whatsapp. Tahap berikutnya adalah menyajikan informasi selayang pandang tentang produk kerajinan anyaman sokasi khas Desa Landih. Kami juga memberikan informasi tambahan yakni produk ini merupakan karya dari komunitas ibu-ibu miskin di Desa Landih. Ini bertujuan mengedukasi masyarakat bahwa dengan membeli produk kerajinan anyaman sokasi ini, akan membantu usaha ini tetap eksis serta membantu memperbaiki taraf hidup kelompok ibu-ibu pengrajin. Informasi ini dirasa sangat penting sehingga akan kami selipkan di kolom 
deskripsi website. Tahap berikutnya yaitu penerapan metode promosi online via Facebook apps dan Instagram apps. Metode promosi jenis ini merupakan bentuk penyesuaian karakteristik konsumen dan masyarakat pada umumnya yang mayoritas menggunakan media sosial Facebook dan Instagram.

\section{RESULTS AND DISCUSSION}

Pelaksanaan kegiatan pengabdian kepada masyarakat dimulai dengan melakukan pertemuan dengan mitra pada tanggal 1 Mei 2021 terkait sosialisasi yang akan diberikan. Adapun kegiatan yang dilakukan pada saat itu yakni seluruh anggota tim pengabdian kepada masyarakat turut terlibat dalam pengadaan dan penyerahaan bahan baku serta bahan penolong penunjang produksi sebagai bentuk investasi kepada mitra. Adapun bentuk pengadaannya yakni bahan baku berupa bamboo dan bahan penolong berupa cat. Kami juga memberikan bantuan berupa peralatan baru untuk berproduksi seperti gergaji, pisau, dan kuas untuk menggantikan peralatan lama yang telah usang dan telah habis umur ekonomisnya. Hasil yang didapat pada pertemuan pertama menunjukkan bahwa mitra sangat terbantu dengan adanya sarana dan prasana baru yang dapat menunjang serta meningkatkan kualitas produksi kerajinan bambu. Hal ini dikarenakan sarana dan prasarana merupakan salah satu komponen penting yang dapat menunjang keberhasilan suatu usaha (Murti \& Murwandani, 2018). Dengan adanya sarana dan prasarana proses produksi akan lebih cepat dan mudah, dan secara tidak langsung akan meningkatkan kualitas produksi (Tanjung, 2021).

Kunjungan kedua dilakukan tanggal 14 Mei 2021. Adapun kegiatan yang dilakukan pada saati itu yakni: kegiatan pertama yakni memperkenalkan aplikasi yang bernama "Buku Kas" oleh ketua yang dibantu anggota I. Aplikasi ini dapat diunduh secara gratis di playstore dan diakses via smartphone android. Dalam kegiatan ini juga telah disiapkan buku peraga yang mengandung informasi tata cara pengoperasian aplikasi Buku Kas (manual book). Sehingga apabila dalam perjalanan penggunaan aplikasi ini terjadi kendala, maka mitra dapat langsung melihat panduannya pada buku peraga yang telah diberikan. Pada aplikasi Buku Kas telah tersedia secara lengkap menu yang berkaitan dengan pencatatan keuangan usaha (Putra, 2020). Kegiatan dilakukan dengan memperkenalkan dan mengajarkan mitra mulai dari input transaksi penjualan, harga pokok penjualan, input pengeluaran, pencatatan supplier ataupun pelanggan. Mitra juga dapat melakukan pencatatan terkait hutang dan piutang, serta mengatur pengingat tanggal jatuh temponya. Sistem pada aplikasi akan memberikan informasi pengingat bagi mitra terkait nama pelanggan ataupun supplier beserta nominal utang ataupun piutangnya. Aplikasi juga menyediakan menu terkait pembayaran hutang dan pelunasan piutang. Hal yang tak kalah pentingnya adalah mitra dapat mengunduh laporan hutang ataupun piutang serta laporan keuangan sederhana sesuai dengan jangka waktu yang diinginkan. Dengan segala kemudahan yang diberikan oleh aplikasi Buku Kas, sangat terlihat antusiasme mitra dalam memperhatikan dan mempraktekkan aplikasi ini. Pencatatan transaksi keuangan dan penyediaan laporan keuangan sangat bermanfaat bagi mitra untuk mengetahui posisi keuangan serta hasil dari usaha yang dijalankan baik itu jangka waktu harian, mingguan atau bulanan (Purwanti, 2017). Output laporan yang dihasilkan juga mampu menjadi alat kontrol untuk menyesuaikan saldo kas pada laporan dan saldo kas di tangan (cash on hand) (Martini et al., 2019).

Kegiatan kedua yakni pemaparan materi terkait metode pemasaran berbasis $e$ marketing dilakukan oleh Anggota II dengan dibantu oleh anggota III. Tahap awal adalah memperkenalkan website yang telah dibuat lengkap dengan katalog produk disertai dengan varian jenis produk, harga, dan ukuran serta dilengkapi dengan link yang langsung terhubung ke aplikasi whatsapp sehingga akan memudahkan konsumen ketika melakukan pesanan pembelian. Pada website kemudia disisipkan selayang pandang tentang produk kerajinan 
anyaman sokasi khas Desa Landih serta memberikan informasi tambahan yakni produk ini merupakan karya dari komunitas ibu-ibu miskin di Desa Landih. Ini bertujuan mengedukasi masyarakat bahwa dengan membeli produk kerajinan anyaman sokasi ini, akan membantu usaha ini tetap eksis serta membantu memperbaiki taraf hidup kelompok ibu-ibu pengrajin. Tahap berikutnya yaitu penerapan metode promosi online via Facebook apps dan Instagram apps. Metode promosi jenis ini merupakan bentuk penyesuaian karakteristik konsumen dan masyarakat pada umumnya yang mayoritas menggunakan media sosial Facebook dan Instagram. Pemanfaatan kemajuan teknologi digital di era globalisasi merupakan bentuk relevansi marketing dalam upaya memasarkan produk khususnya untuk menjangkau audiens yang lebih luas dengan lebih berfokus pada foto atau gambar.

Hasil dari pelaksanaan sosialisasi terkait metode pemasaran berbasis e-marketing menunjukkan bahwa ibu-ibu kelompok usaha Sari Murni sangat antusias dalam mengikuti sosialisasi, sehingga mereka lebih mudah paham dalam penggunaannya website penjualan. Penggunaan metode pemasaran e-marketing sangatlah dibutuhkan di era modern seperti saat ini, dimana dengan penggunaan media sosial sebagai perantara akan dapat memperluas jangkauan pemasaran serta meningkatkan jumlah penghasilan. Pemanfaaan media sosial menjadi faktor krusial yang dapat mempengaruhi keberlangsungan UMKM, hal ini dikarenakan penggunan teknologi (media sosial) dapat membantu UMKM dalam meningkatkan penjualan sebesar 10-50\% (Berlilana et al., 2020). Media sosial merupakan fenomena baru yang telah mengubah cara lingkungan bisnis berjalan, dimana melalui media sosial kegiatan bisnis mendapatkan akses yang tidak terbatas sehingga dapat membantu perusahaan atau individu meningkatkan kontak mereka dengan pelanggan dan pemasok. (Hidayat et al., 2017).

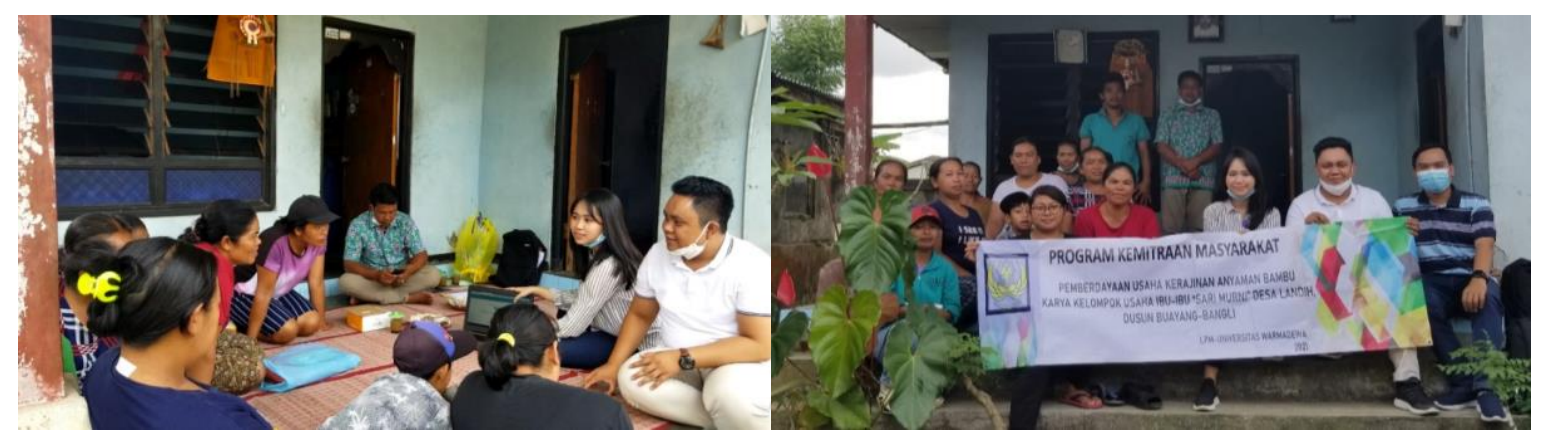

Gambar 3. Pelaksanaan Sosialisasi

\section{CONCLUSION}

Hasil dari kegiatan ini yakni teratasinya kesulitan dalam hal pemenuhan kebutuhan bahan baku bambu dan bahan penolong seperti pewarna cat, kuas, gergaji, dan pisau. Kedua yakni terjadi peningkatan pemahaman, efisiensi serta efektivitas proses pencatatan transaksi keuangan. Kemudian hasil ketiga yakni peningkatan hasil penjualan melalui penerapan strategi e-marketing. Adapun saran yang kami berikan yaitu sebagai bentuk sustainabilitas program maka perlu untuk dilakukan pembinaan dan pendampingan secara berkelanjutan. Tujuannya adalah agar mitra dapat secara fasih mengimplementasikan program yang ditawarkan.

\section{REFERENCES}

Abdillah, M. B., Marsha, R., Hakim, A., Damiri, D. M., \& Zahra, F. (2017). Business Strategy Analysis On Smes Bamboo Crafts In Bandung City Di Kota Bandung. 
Jurnal

AdBispreneur,

2(3),

$227-242$.

http://jurnal.unpad.ac.id/adbispreneur/article/view/16491/7810.

Aprinta, G. (2016). Pemanfaatan Facebook Ads Untuk meningkatkan Brand Awareness pada Produk Lokal. Journal The Messenger, 8(1), 68-72. http://dx.doi.org/10.26623/themessenger.v8i1.310.

Ayu, E. (2013). Aplikasi Instagram sebagai Media Komunikasi Pemasaran Online Shop. Skripsi, 1-21.

Berlilana, Utami, R., \& Baihaqi, W. M. (2020). Pengaruh Teknologi Informasi Revolusi Industri 4.0 terhadap Perkembangan UMKM Sektor Industri Pengolahan. Matrix: Jurnal Manajemen Teknologi Dan Informatika, 10(3), 87-93. https://doi.org/10.31940/matrix.v10i3.1930.

Dewi, A. (2018). Pengaruh Iklan Online Melalui Instagram Terhadap. Jurnal Ekonomi $\begin{array}{llll}\text { Universitas } & \text { Kadiri, } & 3(1), & 1-22 .\end{array}$ kediri.ac.id/index.php/ekonika/article/view/29.

Haryono, S. (2018). Pengaruh Penggunaan Website terhadap Penjualan Produk Pengusaha UMKM pada Asosiasi Industri Kreatif Depok. Sosio E-Kons, 10(1), 39. https://doi.org/10.30998/sosioekons .v10i1.2324.

Hidayat, S., Suryantoro, H., \& Wiratama, J. (2017). Pengaruh Media Sosial Facebook Terhadap Perkembangan E-Commerce Di Indonesia. Simetris : Jurnal Teknik Mesin, Elektro Dan Ilmu Komputer, 8(2), 415. https://doi.org/10.24176/simet.v8i2.1165.

Huda, O. V. N., Hermawan, H., \& Suharto, A. (2019). Pemanfaatan Media Facebook Dan WhatsApp Sebagai Promosi Untuk Meningkatkan Penjualan Di UMKM GPS Sablon. Universitas Muhammadiyah Jember.

Indika, D. R., \& Jovita, C. (2017). Media Sosial Instagram Sebagai Sarana Promosi Untuk Meningkatkan Minat Beli Konsumen. Jurnal Bisnis Terapan, 1(01), 25-32. https://doi.org/10.24123/jbt.v1i01.296.

Irhandayaningsih, A. (2017). Pengaruh Penggunaan Teknologi Tepat Guna dalam Meningkatkan Produktivitas UKM Batik Tulis di Kampung Batik Kauman Kota Pekalongan. Anuva, 1(1), 11. https://doi.org/10.14710/anuva.1.1.11-18.

Lesmana, I. P. D., Widiawan, B., \& Hartadi, D. R. (2018). Pengembangan Pemasaran Online Kerajinan Anyaman Bambu Antirogo Jember Melalui Media Internet. Jurnal Bakti Masyarakat Indonesia, 1(1), 17-24. https://journal.untar.ac.id/index.php/baktimas/article/view/1873/1036.

Malihah, N., \& Achiria, S. (2019). Peran ekonomi kreatif dalam pemberdayaan industri kerajinan bambu. Jurnal Kajian Ekonomi Islam, 4(1). https://doi.org/http://dx.doi.org/10.15548/maqdis.v4i1.212.

Martini, R., Agustin, R., Fairuzdita, A., \& Murinda, A. N. (2019). Pengelolaan Keuangan Berbasis Aplikasi Sistem Keuangan Desa. Jurnal Pengabdian Kepada Masyarakat, 25(2). https://doi.org/10. 24114/jpkm.v25i2.13916.

Murti, K. A. H., \& Murwandani, N. G. (2018). Kerajinan anyam bambu di sanggar hamid jaya desa gintangan kecamatan rogojampi kabupaten banyuwangi. Jurnal Seni Rupa, 6(1), https://jurnalmahasiswa.unesa.ac.id/index.php/va/article/view/22432/20568.

Oktaria Ardika Putri. (2019). Social Innovation Sebagai Strategi Meningkatkan Penjualan Di $\begin{array}{llll}\text { Era Revolusi } & \text { Industri } & \text { 410-417. }\end{array}$ http://ojs.senmea.fe.unpkediri.ac.id/index.php/senmea/article/view/13.

Pradiani, T. (2018). Pengaruh Sistem Pemasaran Digital Marketing Terhadap Peningkatan Volume Penjualan Hasil Industri Rumahan. Jurnal Ilmiah Bisnis Dan Ekonomi Asia, 11(2), 46-53. https://doi.org/10.32812/jibeka.v11i2.45.

Pratiwi, ayu ratih. (2018). Analisis Potensi Ketersediaan Tanaman Bambu dan Pemasaran 
Kerajinan Bambu di Desa Kayubihi Kecamatan Bangli Kabupaten Bangli. Jurnal Agribisnis Dan Agrowisata (Journal of Agribusiness and Agritourism), 7(3), 405. https://doi.org/10.24843/jaa.2018.v07.i03.p10.

Purwanti, E. (2017). Analisis Pengetahuan Laporan Keuangan Pada Umkm Industri Konveksi Di Salatiga. Jurnal of Economic and Bisnis, 10(2). https://jurnal.stieama.ac.id/index.php/ama/article/view/ 152/142.

Putra, A. P., \& Dewi, P. A. R. (2020). Efektivitas Terpaan Iklan Ads Instagram Tiket.Com Pada Pengguna Instagram Menggunakan Metode Pendekatan Epic Model. Commercium, $\quad 02, \quad$ 134-138. https://jurnalmahasiswa.unesa.ac.id/index.php/Commercium/article/view/31841.

Putra, N. P. (2020). Pemberdayaan Masyarakat Pada Kelompok Usaha Loloh Cemcem Di Desa Penglipuran Kabupaten Bangli. International Journal of Community Service Learning, 4(4). https://doi.org/10.23887/ijcsl.v4i4.29680.

Roy, I. W., Putra, A., Made, D., Purnawati, O., \& Maryati, T. (2019). Sejarah Industri Kerajinan Bambu Di Desa Kayubihi ,Bali Sebagai Sumber Belajar Sejarah Lokal Di Sma.

Susanti, S., Rachmaniar, \& Koswara, I. (2020). Pelatihan Daring Aplikasi Media Sosial dalam Pemasaran Produk Kerajinan Bambu di Selaawi, Garut, Jawa Barat. Jurnal Pengabdian Pada Masyarakat, 5(4), 943-953. https://doi.org/https://doi.org/10.30653/002.202054.666.

Susanto, A., Sari, C. A., Moses, D. R. I., Rachmawanto, E. H., \& Mulyono, I. U. W. (2020). Implementasi Facebook Marketplace untuk Produk UMKM sebagai Upaya Peningkatan Pemasaran dan Penjualan Online. Abdimasku: Jurnal Pengabdian Masyarakat, 3(1), 42. https://doi.org/10.33633/ja.v3i1.64.

Tanjung, Y. (2021). Pelatihan Kewirausahaan Dalam Mengelola Bahan Limbah Batok Kelapa Menjadi Lampu Hias, Lonceng, Asbak Dan Teko Pada SMK Negeri 1 Beringin. Jurnal Pengabdian Kepada Masyarakat, 3(1), 11-14. http://jurnal.harapan.ac.id/index.php/Prioritas/article/view/372.

Tata, Y. R. (2019). Mengurai Peta Jalan Akuntansi Era Industri 4.0. Referensi : Jurnal Ilmu Manajemen Dan Akuntansi, 7(1), 58. https://doi.org/10.33366/ref.v7i1.1339.

Ulfah, S. C., \& Purfini, A. P. (2020). Implementasi Aplikasi Buku Kas Umum Berbasis Website Di Desa Ciwaruga Kecamatan Parongpong Kabupaten Bandung Barat. Jurnal Pengabdian Kepada Masyarakat Sistem Informasi Akuntansi, 1(1), 23-29. https://ojs.unikom.ac.id/index.php/abdikamsia/article/ view/4588/2435.

Warsadi, K. A., Herawati, N. T., \& Julianto, I. P. (2017). Penerapan Penyusunan Laporan Keuangan Pada Usaha Kecil Menengah Berbasis Standar Akuntansi Keuangan Entitas Mikro, Kecil, Dan Menengah Pada PT. Mama Jaya. Jurusan Akuntansi, 8(2). https://ejournal.undiksha.ac.id/index.php/ S1ak/article/view/13773/8561.

Wastutiningsih, S. P., \& Dewi, T. P. (2019). Community Empowerment Based on Micro, Small, and Medium Business Development in The Industrial 4.0 Revolution. Suluh Pembangunan: Journal of Extension and Development, 1(2), 90-96.

Zahrul Atiq, A., \& Syaichu, A. (2017). Pengaruh Promosi Menggunakan Facebook Ads Untuk Meningkatkan Volume Penjualan Cokelat Japo. Ilmu - Ilmu Teknik - Sistem, 14(3), 1-11. 